\title{
Urea Receptors which Have Both a Fat Brown RR and a Nitrophenyl Group as a Signaling Group
}

\author{
Sung kỵu Lec and Jongmin Kang

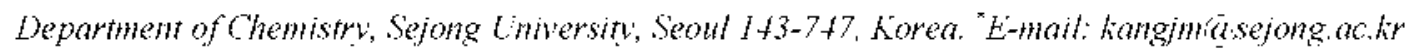 \\ Recened September 18, 2009, iccepted October 23, 2009
}

\begin{abstract}
A new eolorimetric anion sensor 1 has been synthesized based on both Fat brown RR dye and a nitrophenyl group. This new reeptor 1 eould recognize the presenee ol tuoride ion elleetively and selectively by the ehange of eolor of solution. In addition, reeptor 1 shosts higher altinity for acelate, dihydrogenphosphate and hy drogensulfate than the other anions such as chloride, bromide, iodide, perehlorate. and nitrate in acetonitrile.
\end{abstract}

Key Words: Anion receptor. Urea, Colorimetric receptor. Anion recognition

\section{Introduction}

Ureas and thioureas participatc in bifurcatc $\mathrm{H}$-bond interactions and have been used as binding fragments in the design of

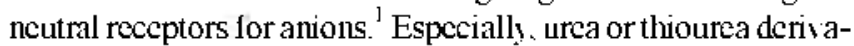
tives connected with a series of chromogenic and fluorogenic substituents proved to be very efficient for the anion sensors. The interaction with anion ty pically stabilizes the excited state of chromophore and induces red shift of the charge transfer absorption band. thus providing an efficicnt way for qualitative and quantitative evaluation of anion activity in solution. ${ }^{3}$ They can be often easily synthesized from commercially available reagents even by a single step procedure. ${ }^{4}$ We have also reported on noycl colorimetric receptors containing a nitroplenyl group as chromogenic signaling subunil and urea as binding sites. which were selective for fluoride or acetate ion. ${ }^{5}$

As a part of our efforts to dev elop more efficient anion receptors. we planned to design a new colorimetric anion sensor 1 utilizing both Fat brown RR dye and nitrophemyl group as chromogenic signaling sites and urea moiety as binding sites.

The receptor 1 was found to be an efficient detector for fluoride ion by the change of UV-Vis. ${ }^{l} H$ NMR spectra and the naked-cyc observation. Receptors 1 was sy nthesized using the one step reaction of Fat Brown RR and 4-nitrophenyl isocyanate in a reasonably good yicld (Scheme 1).

The receptor 1 displayed strong absorption bands at $330 \mathrm{~mm}$ and $435 \mathrm{~cm}$ in accionitrile. Figure 1a shows the family of spectra obtained over the course of the titration of the solution 1 with tetrabutylammonium fluoride in acetonitrile. As tetrabutylammonium fluoride was added to the $30 \mu \mathrm{M}$ solution of 1 . the intensity of absorption spectrum decreased at $330 \mathrm{~mm}$ and increased at $383 \mathrm{~nm}$ and $435 \mathrm{~mm}$. In addition. $h_{\text {nnux }}$ of 1 at 330 nm and $4.35 \mathrm{~nm}$ showed red shift. the solution color changes from yellow to red as the concentrations of anions were increased and the clear isosbestic point appears at $356 \mathrm{~mm}$ This result suggests that a typical hydrogen bonding complex forms between the receptor and the antion. Assuming 1:1 stoichiome1r, a Benesi-Hildebrand plot by use of change in the 385 wu absorption intensity gave association constants. From the experiments, the receptor 1 showed association constants $5.0 \times$
$10^{3}$ for fluoride. The binding plenomenon could be confinmed by a ${ }^{1} \mathrm{H} N M R$ tilation in $\mathrm{CD}_{3} \mathrm{CN}$ (Figure 2). As the N-H hy drogen peak became invisible upon addition of fluoride ion, the aromatic signal $\left(\mathrm{H}_{i 1}\right.$. Scheme l) located next to urea $(8.85 \mathrm{ppm})$ was used for titration. For the receptor 1, this aromatic signal moved from 8.85 ppm $109.10 \mathrm{ppm}$ until 5 oquivalents of huoride ion was added. In fact. two effects are expected as a result of hydrogen bond formation between the urea subunit and the anion. (i) A through-bond propagation increases electron densily in the phenyl ring, which causes a shiclding effect and promotes an upfield shift (ii) A through-space effect increases a polarization of $\mathrm{C}-\mathrm{H}$ bonds, which causes deshielding and promotes a downficld shift. In this case. the clectrostatic effect dominates. and a downlicld shift is obseried. Analy sis of chemical shift utilizing EQNMR ${ }^{*}$ gave association constant $4.7 \times$ $10^{3}$. which is similar value obtained from UV-Vis titration.

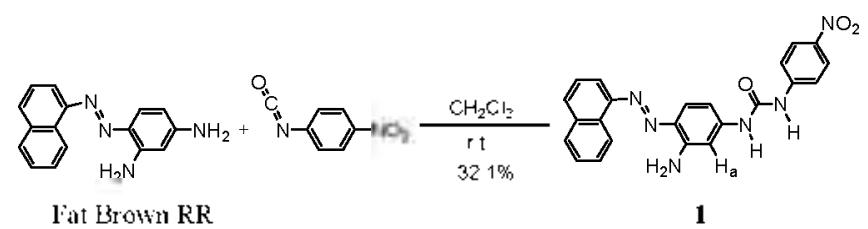

Scheme 1. The synthetic procedure for the anion receptor 1 (a)

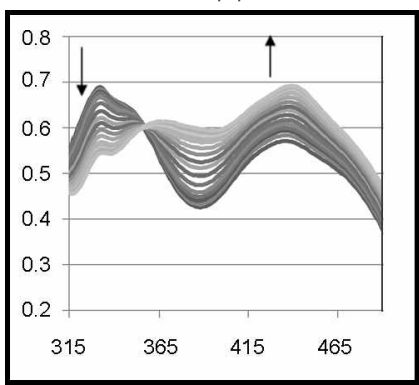

(b)

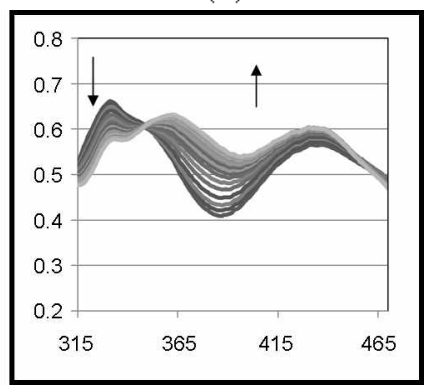

Figure 1. liamily of spectra recorded over the course of titration of 30 $\mu \mathrm{M}$ acetonitrile solution of the receptor 1 with a slandard solution tetrabuly lammonium lluoride (a) and acetate (b). 


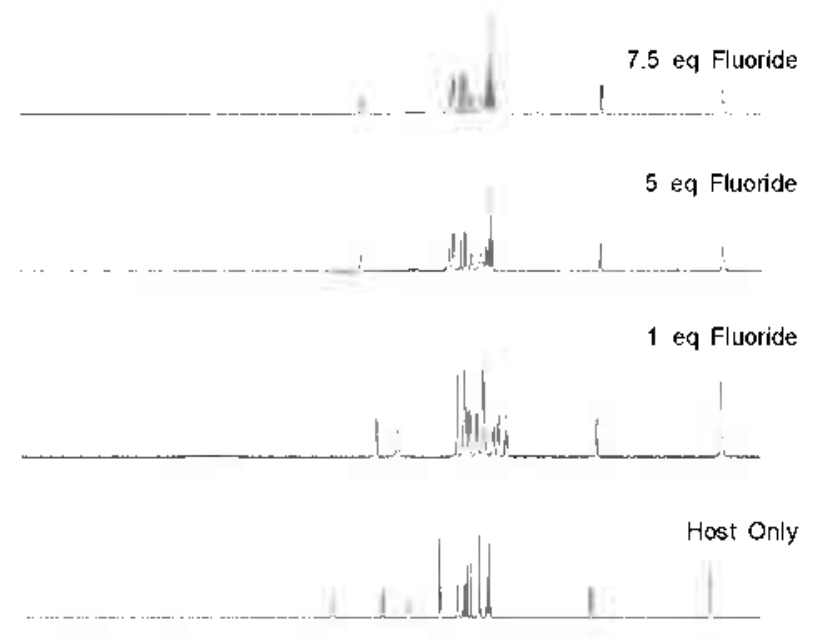

$12.512011 .511 .010 .51009 .5 \quad 9.0 \quad 8.5 \quad 8.0 \quad 7.5 \quad 7.0 \quad 6.5 \quad 6.0 \quad 5.5 \quad 5.0$ poin

Figure 2. 'H.VMR spectra of $2 \mathrm{mM}$ solution of 1 with increased amounts of tetrabutylammonium fluoride in $\mathrm{CD}_{3} \mathrm{C} N$

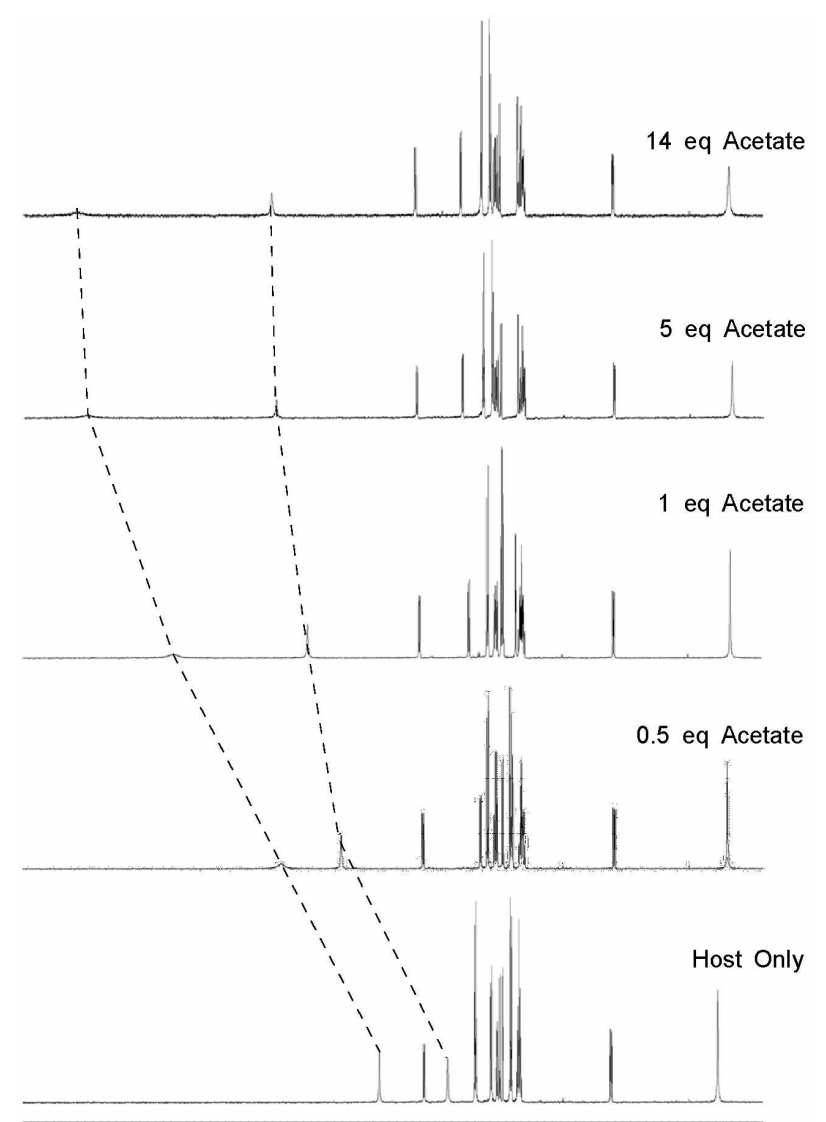

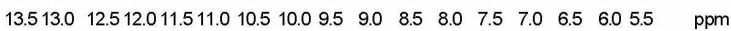

Figure 3. 'I I NMR spectra of $2 \mathrm{mM}$ solution of 1 with increased amounts of tetrabutylammonium acetate in $\mathrm{CD}_{3} \mathrm{C}$. D. Downfield shift of urea peaks are designated by dotled line.

With acetate, Both UV-Vis titration spectrum and 'I NMR spectrum showed evidence of a discrete hydrogen-bonded com
Table 1. The association constants of the receptors 1 with tetrabutylatrmonıum anions in acetonitrile

\begin{tabular}{lcc}
\hline Anion & Ka from UV-Vis titration & $*$ Ka from 'H AMR titration \\
$\mathrm{F}$ & $5.0 \cdot 10^{3} \pm 2.5 \times 10^{2}$ & $4.7 \times 10^{3}$ \\
$\mathrm{Cll}_{3} \mathrm{CO}_{2}$ & $3.3 \times 10^{3} \pm 1.7 \times 10^{2}$ & $4.1 \times 10^{3}$ \\
$\mathrm{HSO}_{4}$ & $2.7 \times 10^{3}+1.4 \times 10^{2}$ & - \\
$\mathrm{H}_{2} \mathrm{PO}_{4}$ & $2.6 \cdot 10^{3} \pm 1.3 \cdot 10^{2}$ & - \\
$\mathrm{NO}_{3}$ & $2.0 \cdot 10^{3} \pm 1.0 \cdot 10^{2}$ & - \\
$\mathrm{Cl}$ & $1.3 \times 10^{3}+65 \times 10$ & - \\
$\mathrm{Br}$ & $1.0 \cdot 10^{3} \pm 5.0 \times 10$ & -
\end{tabular}

${ }^{*}$ Errors in Ka are estimated in less than 10\%

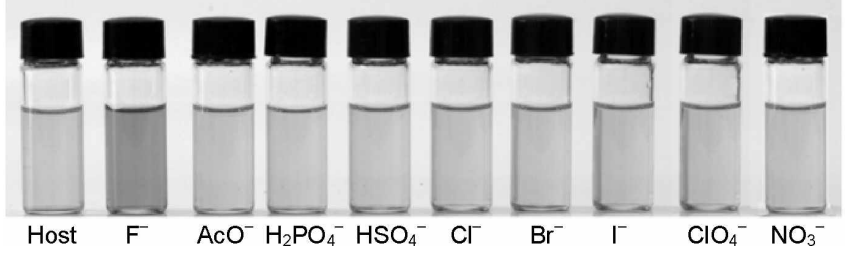

Figure 4. The color changes of the receptor 1 when $50 \mu \mathrm{M}$ solution of the receptor was treated with 10 ecpuvalents of various anions in acetonitrile.

plex. In case of UV-Vis titration, as tetrabutylammonium acetate was added to the $30, \mathrm{l} \mathrm{M}$ solution of 1 , the intensity of absorption spectrum decreased at $330 \mathrm{~nm}$ and increased at $383 \mathrm{~nm}$ and 435 $\mathrm{nm}$. [n addition, the clear isosbestic point appears at $345 \mathrm{~nm}$ (Figure lb). In case of ${ }^{1} \mathrm{H}$ N.MR titration, as tetrabutylammonium acetate was added, 1wo urea peaks moved to downfield (from 9.43 and $8.54 \mathrm{ppm}$ to 13.30 and $10.81 \mathrm{ppm}$ ) with broadening of signals, which suggests that the typical hydrogen bonding complex between the receptor and the anion. (Figure 3) The association constants obtained from $\mathrm{C}, \mathrm{V}$-Vis spectrum and ${ }^{\prime} H$.VMR titration were $3.3>10^{3}$ and $4.1,10^{3}$ respectively.

We also investigated association constants of other anions. Among the anions investigated tetrahedrally shaped anions such as dihydrogenphosphatc, and hydrogensul fatc have higher affinity than spherically shaped anions such as halides. The binding constants of these anions from UV-Vis titration were summarized in Table I.

Figure 4 shows the color change of the solutions of the receptor I upon additions of various anions in acetonitrile. It can be seen that the color changed from yellow to orange in the presence of fluoride anion with naked eyc. Other anions did not induce any color changes even with excess amounts. Probably, as we can see from the NMR titration with fluoride ion, deprotonation of the receptor 1 by the fluoride induces the change of the color.

In summary, we developed a new chromogenic anion receptor 1 with utilizing Fat Brown RR and nitrophenyl group as signaling group. The receptor 1 binds anions via hydrogen bonds with a selectivity of $\mathrm{F}>\mathrm{CH} \mathrm{I}_{3} \mathrm{CO}_{2}>\mathrm{ISO}_{4} \sim 1 \mathrm{H}_{2} \mathrm{PO}_{4}>\mathrm{NO}_{3}>$ $\mathrm{Cl} \cdots \mathrm{Br}$ and proved to be an efficient naked-eye detector for the fluoride ion. 


\section{References}

1. Gale, P. A. Annde and Lirea Based receptors in Encyclopedia of Supramolecthlar Chemistn: marcel Dekker: New York, 2004: $p$. 31

2. (a) Tose, D. A.: Kumar, D. K.; Gangulv; B.Das, A. Org. Lett. 2004 6,3445 (b) Havashita, T; Onodera, T.; Kato, R.; Nishizawa, S.: Teramae, N. Chent Conmmu 2000, 755; (c) Tozawa, T.; Misawa, Y.; Tokita, S.: Kubo, Y. Tetrahedron Lett. 2000, 11, $521 \%$ (d) Kato, R.: Nishizawa, S.: Hayashita, T.: Teramae, N. Tetrahedron Lett. 2001, 42, 5053; (e) Gumnlaugsson, T; Davis, A. P.; Glynn, M. Chem. Commun 2001, 2556: (f) Sasaki, S. Citterio, D.; Ozawa, S: Suzuki, K. J. Chem. Soc. Perhin Trans. 2001, 2309; (g) Lee, D. H.: Lee, H. Y.: Lee, K. H.: Hong, T.-I. Chem. Commm. 2001, 1188 : (h) Henurich, G.; Sonnenscheir, H.; Resch-Genger, U. Tetrohedront Leth. 2001, 42, 2805; (i) Mei, M. H.; Wu, S. K. Acta Chm. Sin. 2001, 59, 1112; (j) Jiménez, D; Martínez-Mániez, R:; Sancentón, F.: Soto, I. Tetrahedron Lett 2002, 43,2823 ; (k) Lee, D. H.: Lee, H. Y: Hong, J.-I. Tetrahedron Lett. 2002, 43, 7273; (1) Kondo, S: Nagamine, M.; Yano, Y. Tetrahedron Lett. 2003, $4,4,8801$ : (m) Gunnlaugsson, T.; Kuuger, P. E.; Lee, T. C.: Parkesh, R.; Pfeffer, F. M.; Hussey, G. M. Tetrahedron Lett. 2003, H, 6575; (n) Sansone, F.: Chierici, E.: Casnati, A.: Ungaro, R. Org. Biomol. Chem. 2003, 1 , 1802; (o) Gumnlaugsson, T.; Davis, A. P.; Hussey, G. M.; Tiemey, T.; Glym, M. Org. Bionol. Chent 2004, 2, 1856; (p) Lee, J. Y: Cho, E. I.; Mukamel, S.; Nam, K. C.J.Org. Chem. 2004, 69, 943; (q)
Cho, E. J.; Moon, J. W.; Ko, S. W. Lee, J. Y.; Kim, S. K: Yoon, T.: Nam, K. C. J. Am. Chem. Soc. 2003, 125, 12376: (r) Kim, S. K: Singh, N. T.; Kim, S. J.; Swany, K. M. K.; Kim, S. H.; Lee, K.-H.; Kim, K. S.; Yoon, J. Tetrahedron 2005, 61, 4545.

3. (a) Martínez-Máñez, R; Sancenón, F. Chem. Rev: 2003, 105, 4419; (b) Suksai, C.; Tuntulani, T. Chem. Soc: Rev $2003,32,192$.

4. (a) Kang, S. O.; Linares, J. M.; Powell, D; VanderVelde, D.; Bowman-James, K. J. Ant. Chem. Soc. 2003, 125, 10152; (b) Kondo, S.-I.; Hiraoka, Y; Kurumatani, N.; Yano, Y. Chem. Conmmin. 2005, 1720; (c) Xie, H.; Yi, S.; Wu, S. J. Chent. Soc., Perkin Trons. 21999,2751

5. Kim, H.; Kang, J. Bull. Korean Chem. Soc: 2007, 28(9), 1531.

6. To a solution of $100 \mathrm{mg}(0.38 \mathrm{mmol})$ of Fat Brown RR in $5 \mathrm{~mL}$ of dichloromethane was added $62.4 \mathrm{mg}(0.38 \mathrm{mmol})$ of 4-nitropheny. isocyanate and the mixture was stired for 6 hours at room temperature. After the solvent was evaporated from the reaction mixture, the remained solid was washed by dichloromethane. Chromatography on the silicagel (Hexanle: Ethyl acetate $=3: 1$ ) gave $52 \mathrm{mg}$ of red solid product in $32.1 \%$ yield ${ }^{\mathrm{l}} \mathrm{H}$ NMR (DMSO- $d_{s}$ ) $10.5(\mathrm{~s}, 1 \mathrm{H}), 9.5(\mathrm{~s}, 1 \mathrm{H}), 8.9(\mathrm{~d}, J=8.0,1 \mathrm{H}), 8.2(\mathrm{~d}, J=9.0,2 \mathrm{H}), 80$ $(\mathrm{m}, 3 \mathrm{H}), 7.9(\mathrm{~d}, J=9.0,1 \mathrm{H}), 7.8(\mathrm{~d}, J=9.0,2 \mathrm{H}), 7.7(\mathrm{~s}, 1 \mathrm{H}), 7.6$ $(\mathrm{m}, 3 \mathrm{H}), 6.4(\mathrm{~s}, 2 \mathrm{H}), 6.4(\mathrm{~d}, J=9.0,1 \mathrm{H})$ LRMS (ES) calculated for $\mathrm{C}_{23} \mathrm{H}_{18} \mathrm{~N}_{6} \mathrm{O}_{3}, 426.14$; found for 426.15 .

7. Benesi, H.; Hildebrand, H. J. Am. Chem. Soc. 1949, 71, 2703.

8. Hynes, M. I. J. Chem. Soc., Dalton Trans. 1993, 311. 